This is the author's accepted version of the following chapter: Vickers, T. (2015) 'The contribution of UK asylum policy 1999-2010 to conditions for the exploitation of migrant labour', in L. Waite, G. Craig, H. Lewis and K. Skrivankova (eds), Vulnerability, exploitation and migrants: Insecure work in a globalised economy, London: Palgrave MacMillan, pp 101-14. The version of record is available at:

\title{
The contribution of UK asylum policy 1999-2010 to conditions for the exploitation of migrant labour
}

Tom Vickers

\begin{abstract}
This chapter analyses UK asylum policies since 1999 in the context of wider neoliberal approaches to migration, which present labour market demand and personal wealth as the dominant criteria for mobility. It considers refugee claims as an implicit challenge to these criteria because they are universal and needs-based. It argues that dispersal, prohibition of paid work and detention of asylum seekers have countered this challenge and thereby reinforced labour market discipline over migrants.
\end{abstract}

\section{Introduction}

This chapter argues that our understanding of UK asylum policies can be deepened through a political economy analysis. The chapter focuses on the period 1999-2010, drawing on research conducted in Newcastle upon Tyne between 2007 and 2010 (also see Vickers 2012; 2014a; 2014b). ${ }^{\mathrm{i}}$ Policy changes directed at asylum seekers ${ }^{\mathrm{ii}}$ during this period included forced dispersal from 1999, prohibition of paid work from 2002, and a significant increase in immigration detention. These policies, alongside the detained fast track system and reductions in access to appeals and legal aid, amount to an increasingly punitive system that has been widely criticised by bodies such as the Independent Asylum Commission (IAC 2008b), and has provoked widespread resistance from those within the system and their supporters (Anti-Raids Network 2014; Gill et al 2012; Vickers 2014a), yet the overall policy direction has continued. This suggests there may be even more powerful pressures pushing for a continuation of the current direction.

Explanations of the hostile policy climate that focus exclusively on the influence of the media, or voter attitudes, do not explain why these policies have been enacted at this particular time. Indeed, Philo et al (2013) argue that British governments have actively used the media to cultivate public hostility toward refugees. An explanation is also needed for the consistency in policy direction across different political parties in power, including the Labour Party between 1997 and 2010 and the Conservative and Liberal Democrat parties in coalition since 2010, and for the focus on asylum seekers, out of all proportion to their numbers relative to other forms of migration (Cohen 2006: 5-6; Crawley 2006: 22-4). If we consider the distinctive characteristic of asylum to be the claim to citizenship based solely on the needs of a group or individual, then a political economy approach directs attention to some powerful reasons for Britain's capitalist class to restrict asylum during this period:

- The increasing push since the 1970s to further commodify labour power as part of a neoliberaliii policy approach (Lavalette and Pratt 2006), requiring the elimination of claims based on human needs rather than market forces; 
This is the author's accepted version of the following chapter: Vickers, T. (2015) 'The contribution of UK asylum policy 1999-2010 to conditions for the exploitation of migrant labour', in L. Waite, G. Craig, H. Lewis and K. Skrivankova (eds), Vulnerability, exploitation and migrants: Insecure work in a globalised economy, London: Palgrave MacMillan, pp 101-14. The version of record is available at:

- The destruction of the socialist bloc at the end of the 1980s, which both removed the political value of granting asylum to 'dissidents' in order to embarrass their socialist countries of origin (Schuster 2003), and made available a large pool of highly skilled labour in nearby Eastern Europe, who were under economic pressures to migrate (Hardy 2008).

In the context of a policy approach of 'managed migration', with rights to move to Britain increasingly tailored to the labour needs of capital, asylum represented an exception, with claims based on universal human rights. Even where refugees' labour is needed within Britain, the fact that refugees move regardless of whether their labour is needed or not represents a threat to the dominance of neo-liberal criteria. Restrictions on access to asylum between 1999 and 2010 helped counter this threat. Table 1 shows the general decline in numbers of applications between 1999 and 2010, while refusal rates have remained high, exceeding $80 \%$ for three consecutive years and exceeding $70 \%$ in nine out of twelve years.

Table 1: Asylum applications and refusals rates 1999-2010

\begin{tabular}{|l|l|l|}
\hline Year & $\begin{array}{l}\text { Asylum } \\
\text { applications* }\end{array}$ & Refusal Rate** \\
\hline 1999 & 71,160 & $52 \%$ \\
\hline 2000 & 80,315 & $74 \%$ \\
\hline 2001 & 71,025 & $72 \%$ \\
\hline 2002 & 84,130 & $63 \%$ \\
\hline 2003 & 49,405 & $83 \%$ \\
\hline 2004 & 33,960 & $88 \%$ \\
\hline 2005 & 25,710 & $83 \%$ \\
\hline 2006 & 23,610 & $78 \%$ \\
\hline 2007 & 23,430 & $73 \%$ \\
\hline 2008 & 25,930 & $69 \%$ \\
\hline 2009 & 24,485 & $72 \%$ \\
\hline 2010 & 17,790 & $75 \%$ \\
\hline
\end{tabular}

* Includes applications made at the port of entry and after arrival in the UK

** Final decisions made that year, including applications which may have been made in a previous year.

Figures from UK Home Office Immigration Statistics (https://www.gov.uk/government/statistics)

In October 2013 The Observer reported statements by a Home Office spokesperson that officials dealing with asylum cases were expected to secure a rejection in at least $60 \%$ of 
This is the author's accepted version of the following chapter: Vickers, T. (2015) 'The contribution of UK asylum policy 1999-2010 to conditions for the exploitation of migrant labour', in L. Waite, G. Craig, H. Lewis and K. Skrivankova (eds), Vulnerability, exploitation and migrants: Insecure work in a globalised economy, London: Palgrave MacMillan, pp 101-14. The version of record is available at:

cases (Taylor 2013), and in January 2014 The Guardian cited written Home Office guidelines offering rewards to officials meeting a 70\% rejection target (Taylor and Mason 2014). These restrictions on access to asylum contributed to conditions for more intense exploitation of other migrants' labour, by making it more difficult in practice to assert economic, political and social rights. The creation of a separate welfare and housing system for asylum seekers in 1999, the prohibition of paid work in 2002, and the increasing use of immigration detention, all served to make it harder for refugees to build links with non-refugees. This both made it more difficult for refugees to resist the injustices of the asylum system, and countered the potential for refugees from oppressed countries to form alliances with British working class people, by removing opportunities for day to day contact and struggle - over shared conditions of housing and work, for example - which could threaten international divisions of labour.

The remainder of this chapter sketches some key features of the political economy approach that informs this analysis, before discussing the role of migrant labour in the British economy and the implications of specific asylum policies.

\section{British Capitalism and the International Reserve Army of Labour}

This chapter employs an analysis of contemporary capitalism that draws on Lenin's ([1916] 1975) theory of imperialism. Imperialism is understood here as a phase of capitalism characterised by the merger of banking and manufacturing capital into monopoly finance capital, and the division of the world into countries with a high concentration of capital ownership and consequently financial, political and military power, and countries with low levels of capital ownership, whose people and resources are exploited for the benefit of the owners of capital. Based on their relative positions within the international capitalist system, the former countries are characterised as imperialist countries, and the latter as oppressed countries, while recognising that there is a dynamic continuum between the two categories, with continuous struggles for imperialist countries to maintain and extend their dominance relative to their rivals, for less powerful capitalist countries to aspire to imperialist status, and for oppressed countries to mitigate or overturn their oppression. Struggles of oppression and resistance exist within oppressed and imperialist countries, as well as between them, and these are shaped by, and shape, the position of these countries within the imperialist system. The chapter employs an analysis of the state drawing on Lenin ([1917] 1972), as a set of interlocking institutions ultimately serving the interests of the British capitalist class (outlined in more detail in Vickers 2014b).

Countries' position within capitalism has emerged historically, driven by the internal dynamic of the capital accumulation process. Accumulation of capital produces a tendency for the rate of profit to fall (Marx [1894] 2006); eventually an over-accumulation of capital results in insufficient opportunities for investment relative to the mass of accumulated capital, and the accumulation process fails (Grossman [1929] 1992). One of the consequences of this process is that as capital accumulates in the main capitalist centres - the imperialist countries - there is a drive to export capital abroad, to countries with lower concentrations of capital 
and where conditions can be created for a higher rate of profit, maintaining the average rate of profit as an incentive for continued investment. An international division of labour is an integral part of the division of countries into imperialist and oppressed categories (see also Smith's chapter in this collection). Profitable conditions in oppressed countries often include lower health and safety and environmental standards, lower pay and a lower 'social wage' in the form of state services and financial support. In 2011, Britain earned a rate of return on investments in Asia and the rest of the world, excluding the EU and US, of 3.3 per cent and 3.0 per cent respectively, compared to 2.5 per cent return on other countries' investments in the UK (ONS 2013a: 17), a significant difference considering the sums involved. At the end of 2012 Britain's total external assets stood at $£ 10,222.9$ billion (ONS 2013b: 6), more than 6.5 times UK GDP. For Foreign Direct Investment, which accounts for around 10 per cent of the UK's total overseas assets, the UK received rates of return of 19 per cent and 16 per cent respectively for investments in Africa and Asia, compared to a rate of return of 4 per cent on direct investments into the UK (ONS 2013c): this represents a parasitic relationship and conditions of super-exploitation in oppressed countries. Material underdevelopment of countries oppressed within imperialism has historically prevented these countries' domestic production from fulfilling their own populations' needs, thus simultaneously generating markets for imperialist exports, and maintaining a reserve army of labour for imperialist countries (Castells [1975] 2002; Miles 1987; Chinweizu and Jameson 2008).

As Castells ([1975] 2002: 85) argues, the relationship between capital, labour and mobility is not simply economic, but is mediated by political systems and relationships that arise from the economic base and impact back upon it. Control over one's mobility is rooted in a person's relationship to capital, both in terms of where their country of citizenship stands within imperialism, and their class position within that country. As Foster et al (2011: 6) point out, the production of super-profits in oppressed countries through conditions that can be characterised as super-exploitation, depends on the immobility of labour. While capital is free to move across borders, the movement of workers from oppressed countries is therefore heavily regulated (Barber and Lem 2008: 4).

\section{The 'New Migration' from Eastern and Central Europe}

2004 saw a significant development in freedom of movement and employment for citizens designated 'migrant workers' from the 'Accession 8' (A8) countries in Eastern and Central Europe, with the further addition of the 'A2' countries, Romania and Bulgaria, in 2007. Datta et al. (2007) suggest A8 workers may have been a preferred source of labour compared to migrants from outside the EU, both for their 'whiteness' and on the understanding that they would be more likely to return to their country of origin than people who have travelled greater distances (Datta et al 2007: 49). By 2007, there were an estimated 1.4 million registered migrant workers in the UK, around half of whom had arrived from the A8 and A2 countries since 2004, and somewhere between 300,000 and 800,000 unregistered migrant workers (Craig et al 2007: 22). Even for those who were registered, many worked in conditions so exploitative as to meet the international definition of 'forced labour' (Geddes et 
al 2013; Ahmad 2008: 857). The Workers Registration Scheme (WRS) was established, in the words of the Home Office, to provide 'transitional measures to regulate A8 nationals' access to the labour market ... and to restrict access to benefits.' Access to the labour market was regulated by the requirement to register for the WRS, but this did not apply to those classified as 'self-employed'. Those designating themselves self-employed were thereby denied many employment rights, even where they were dependent on a single employer for work (Dwyer et al 2011). While on the WRS, migrants had severely restricted access to unemployment, child and housing benefits. In the first quarter of 2010, 71 per cent of requests by A8 workers for tax-funded, income-related benefits were refused (Home Office 2010: 23-4). This gave these workers a distinct relationship to capital, to the benefit of the capitalist class. It further explains their preference for Eastern European workers over refugees, who, once they were granted refugee status, had far greater rights to remain in Britain and access state support (Chinweizu 2006), although these rights have been reduced by the shift from indefinite leave to remain to an initial five years. Under the WRS A8 migrants only had access to out-of-work benefits once they had completed 12 months in continuous employment. The WRS ended in 2011 and the restrictions on A2 migrants ended in 2014, but were replaced by regulations restricting access to benefits for all EU migrant workers, extending the exploitative conditions previously affecting A8 and A2 migrants to also include the growing numbers of migrants fleeing the results of crisis and austerity in Southern Europe.

\section{Refugees in Britain and the Management of Migration}

Refugees occupy an ambiguous position in the international division of labour, seeking refuge on the basis of universal human rights yet also available to be called on for their labour, depending on the needs of capital (Kay and Miles 1992: 4-7). To the extent that refugees 'put down roots' in Britain and gain access to resources and networks of support, they are in a stronger position to resist the demands of capital and assert greater control over their mobility, based on their own needs and priorities. Refugees have faced significant barriers to integration for a long time (Bloch 2002) and continue to do so (Carnet et al 2014). The ability to put down roots and rebuild their lives in Britain was increasingly obstructed from 1999 by key policy interventions targeted at refugees without status, designated 'asylum seekers'. While the increased use of detention (Silverman 2011) also has significance within these processes of social control (Gill 2009), this chapter will focus on dispersal and the prohibition on paid work, due to their role in isolating refugees within community settings, where it might be expected that there would be more opportunities for integration compared to detention. It draws on qualitative research conducted in Newcastle between 2007 and 2010, which included multiple in-depth qualitative interviews and focus groups with eighteen refugees, some with status and some without, supplemented by interviews with the staff of four voluntary and community sector organisations.

Under the dispersal system, Temple et al. (2005) found asylum seekers' attempts to reconstitute communities were restricted by: allocations of resources, which tended to 
exclude refugees without status from integration initiatives; hostile environments in dispersal areas, which in some cases kept people confined to their homes; and prohibition of paid work (Temple et al 2005: 23-6). These factors were also identified in research I conducted in Newcastle between 2007 and 2010, framed and given added force by the asylum decisionmaking process itself. Overall, the refugees I interviewed presented experiences of the UK asylum process as unreasonable, unclear and unjust. One way of interpreting this is that a fog of complexity and bureaucracy covers up for the fact that a formally 'fair' process is in practice set up to fail all but a few (Tyler 2010), regardless of their need (BID 2009). Access to a fair consideration of cases has been undermined by reductions to legal aid and the right of appeal (IAC 2008b) and an approach to refugees' claims that the Independent Asylum Commission termed a 'culture of disbelief' (IAC 2008a), echoing the findings of the earlier Glidewell Panel in 1996. The political economy approach outlined above suggests this may be a functional arrangement for capitalism, fulfilling two related but contradictory needs of imperialism. On the one hand, the absolute priority accorded to capital's demand for labour as the basis for migrants to live in Britain is reinforced by the likelihood of being refused asylum, necessary for the continuation of the imperialist division of labour. On the other hand, the British state's image as an upholder of universal human rights and liberty is maintained by the formal fairness of the system, which is necessary for the claims to moral authority so often used to justify Britain's imperialist interference and domination in other countries.

\section{Dispersal}

Since 1999 'dispersal' - the forced resettlement of refugees without status to towns and cities across the UK - has been a key element in the British state's attempts to manage refugees. The Immigration and Asylum Act 1999 transferred coordination of housing from local authorities to the National Asylum Support Service (NASS), operating under the direction of the Immigration and Nationality Directorate (IND).

In selecting areas for dispersal, little consideration was given to social and economic infrastructure or existing community networks or resources (Griffiths et al 2005: 41-2), and the main priority in selecting areas was the availability of cheap housing. In many cases refugees were dispersed to largely white areas with high levels of deprivation, which were given no preparation for the new arrivals (Hewitt 2002; Hynes 2011). Racism played a central role in isolating refugees' experiences from the consciousness of British workers (Temple and Moran 2005). Refugees' lack of control over where they are dispersed contributed to particular problems of isolation for some refugees, such as women refugees experiencing domestic violence (Chantler 2010: 96-7). Refugees dispersed to Newcastle from 1999 encountered considerable hostility, as well as solidarity. An article in the local Evening Chronicle is symptomatic of the hostile reception, titled 'Police hunt four illegal immigrants: Asylum seekers go on the run', referring to four men who had come from Holland in the back of a lorry and then run away from the driver (Hickman 2002). While dispersal disrupted existing networks and was carried out in a way that generated hostility 
from some in the areas where asylum-seekers were dispersed, it also led to new forms of resistance (Webber 2012), including alliances between refugees and non-refugees (Vickers 2014a).

A political economy approach can help us to understand the dispersal system as part of a system for managing oppression, in the context of refugees' particular class position in the international capitalist system. Capital has little interest in most refugees remaining in Britain, because they are driven by imperatives that override demand for their labour, and consequently the state has little interest in providing any but the most basic means of survival. The existence of coherent and self-conscious diasporas with a sense of shared identity between immigrants in imperialist countries and their oppressed countries of origin, rather than with the national ruling classes of their new home, poses a threat to national borders on both an ideological and practical level (Gilroy 2001: 124). Major dispersal areas included cities with little history of migration from refugees' countries of origin. The dispersal process thus played a significant political role in breaking up diasporic networks, removing their potential as a basis for resistance, or even a degree of independence from the state. The state has even less interest in helping refugees integrate with other working class people. Such integration could both offer solidarity for refugees' attempts to remain in Britain and advance their rights, and fundamentally threaten the divisions among workers of different countries, which imperialism relies on to undermine resistance to the super-exploitation of oppressed countries. By disrupting connections with other refugees, support networks and other sections of workers, the dispersal system undermined the potential for collective resistance and increased pressure for refugees to accept the positions assigned them in international divisions of labour, concentrated disproportionately in low-paid sectors of the economy, often in far lower-skilled roles than those they are qualified for (Bloch 2007; Cebulla et al 2010; Fletcher 2011).

\section{The Prohibition on Paid Work}

While some categories of migrant workers continued to receive encouragement to come to Britain, most refugees without status were prohibited by law in 2002 from seeking paid work $^{\text {iv }}$ or even accessing work-based training, cutting them off from legal areas of the British labour market (Phillimore and Goodson 2006: 1721). Even prior to this, the 'right to work' had already been restricted to refugees with status and to the 'primary claimant' on each asylum application, and even then only once the person had been in Britain for at least six months (Dumper 2002: v). This excluded many women from paid work as 'secondary claimants' on family members' applications, and legally enforced their role of unpaid domestic work in the reproduction of the labour power of family members who were permitted to do paid work.

In a capitalist society, where survival and self-worth for the majority are tied to the sale of one's labour power, refugees I interviewed in Newcastle spoke about the negative impact on their self-esteem and mental health as a result of forced inactivity due to being denied the right to undertake paid work. The experience of being a refugee, particularly one who has not 
been granted some form of 'leave to remain', was strongly characterised by insecurity and dependency on the state, enforced by the prohibition on paid work:

“... the asylum seeker is limited, he's not allowed to work ... his income is very low, and he doesn't know the outcome of his decision, so any time he can be deported or can be accepted, so he is in limbo ..." (refugee without status, arrived 2002)

This insecurity, and the legal restrictions on many kinds of action which might have improved their situation, contributed to an intense sense of dependency:

"I've always been independent ... but now it's as if I'm in prison ... there's nothing that proves that I'm an adult, I am just at home, just wait[ing] for somebody to give [things to me] ..." (refugee without status from Cameroon, arrived 2008)

By coming to Britain under imperatives other than those of the labour market, refugees have broken discipline with the reserve army of labour and have contradicted the neoliberal terms for international mobility. In response, asylum policies combine to disempower refugees and enforce their dependency on the British state and with it their responsiveness to be redisciplined into the reserve army. This both keeps them in an oppressed position, and manages this situation by enforcing compliance with the terms of their oppression. It also serves as an example of what happens to those who break neoliberalism's imperatives. Such an observation is not meant to imply the impossibility of resistance; indeed, the development of the structures of control described here has been influenced by the interplay between oppression and resistance, as the British state and those seeking to resist its oppression of refugees have each had to shift their tactics in response to the other (Vickers 2014a, 2014b).

\section{Conclusions}

Refugees occupy an indeterminate class position, particularly acute while their cases are under consideration. They are part of the international reserve army of labour, but a "part out of place', with a potential to disrupt the normal functioning of the division of labour on a political as well as an economic level. Refuge from persecution represents a powerful form of needs-based claim, whose severity makes it harder to dismiss compared to more 'ordinary' claims such as access to food and shelter. ${ }^{\mathrm{V}}$ Refugees' trajectory is in most cases from countries oppressed on a national basis, with which they may maintain connections in identity, communication and transfer of resources. Regardless of their class position in their country of origin, their present position within Britain is most often among the poorest sections of the working class, in conditions that hold the potential to forge alliances across racialised divisions (for an example see Vickers 2014a). From 1999, government policy specifically mitigated against this, by breaking up existing networks based on refugees' countries of origin, through dispersal, and impeding the formation of new ones based on common elements of class position within Britain, through a prohibition on paid work. With the exception of individuals who 'escape' the collective position of the majority, for example through paid employment in the refugee sector, the trajectory of most refugees after arrival in Britain is either: if they secure leave to remain, inclusion into a more regularised but still exploited section of the working class; or if they are refused asylum, destitution (British Red 
This is the author's accepted version of the following chapter: Vickers, T. (2015) 'The contribution of UK asylum policy 1999-2010 to conditions for the exploitation of migrant labour', in L. Waite, G. Craig, H. Lewis and K. Skrivankova (eds), Vulnerability, exploitation and migrants: Insecure work in a globalised economy, London: Palgrave MacMillan, pp 101-14. The version of record is available at:

Cross 2010, and see following chapters in this section), highly exploitative conditions of employment, amounting in some cases to forced labour (Lewis et al 2014); or deportation back to the situations they have fled. By undermining rights to remain in Britain and access resources based on human need, rather than labour market demand, this also creates conditions for more intense exploitation of other migrants' labour.

\section{References}

Ahmad, A. N. (2008). "The labour market consequences of human smuggling: 'illegal' employment in London's migrant economy." Journal of Ethnic and Migration Studies 34(6): 853-874.

Anti-Raids Network (2014). "Notes for a brief history of resistance in UK detention centres" https://network23.org/antiraids/2014/05/08/notes-for-a-brief-history-of-resistance-in-ukdetention-centres/ [Accessed 29/08/14]

Barber, P. G. and W. Lem (2008). "Introduction: migrants, mobility, and mobilization." Focaal: European Journal of Anthropology 51: 3-12.

BID (2009). Out of sight, out of mind: experiences of immigration detention in the UK. London, Bail for Immigration Detainees.

Bloch, A. (2002). Refugees' opportunities and barriers in employment and training. London, Department for Work and Pensions.

Bloch, A. (2007). "Refugees in the UK labour market: the conflict between economic integration and policy-led labour market restriction." Journal of Social Policy 37(1): 21-36. Carnet, P., C. Blanchard and F. Apollonio (2014). The Move On Period: An Ordeal for New Refugees. London, British Red Cross.

Castells, M. ([1975] 2002). "Immigrant Workers and Class Struggles in Advanced Capitalism: The Western European experience." The Castells Reader on Cities and Social Theory. I. Susser (ed.). Malden, MA, Blackwell.

Cebulla, A., M. Daniel and A. Zurawan (2010). Spotlight on refugee integration: findings from the Survey of New Refugees in the United Kingdom. London, Home Office.

Chantler, K. (2010). "Women seeking asylum in the UK: contesting conventions." Gender and Migration: Feminist interventions. I. Palmary, E. Burman, K. Chantler and P. Kiguwa. London, Zed Books: 86-103.

Chinweizu, C. (2006). "Asylum and immigration: maximising Britain's economy." Fight Racism! Fight Imperialism!(190 June/July).

Chinweizu, C. and N. Jameson (2008). "Immigration and the reserve army of labour in Britain." Fight Racism! Fight Imperialism!(201 February / March).

Cohen, R. (2006). Migration and its Enemies: Global capital, migrant labour and the nationstate. Aldershot, Ashgate.

Coole, D. (2009). "Repairing civil society and experimenting with power: a genealogy of social capital." Political Studies 57(6): 374-396.

Craig, G., A. Gaus, M. Wilkinson, K. Skrivankova and A. McQuade (2007). Contemporary Slavery in the UK. York, Joseph Rowntree Foundation. 
This is the author's accepted version of the following chapter: Vickers, T. (2015) 'The contribution of UK asylum policy 1999-2010 to conditions for the exploitation of migrant labour', in L. Waite, G. Craig, H. Lewis and K. Skrivankova (eds), Vulnerability, exploitation and migrants: Insecure work in a globalised economy, London: Palgrave MacMillan, pp 101-14. The version of record is available at: https://link.springer.com/chapter/10.1057/9781137460417 8

Crawley, H. (2006). "Forced migration and the politics of asylum: the missing pieces of the international migration puzzle?" International Migration 44(1): 21-26.

Datta, K., C. McIlwaine, J. Wills, Y. Evans, J. Herbert and J. May (2007). "The new development finance or exploiting migrant labour? Remittance sending among low-paid migrant workers in London." International Development Planning Review 29(1): 43-67. Dumper, H. (2002). Missed Opportunities: A Skills Audit of Refugee Women in the Teaching, Nursing and Medical Professions. London, Greater London Authority. Dwyer, P., H. Lewis, L. Scullion and L. Waite (2011). Forced labour and UK immigration policy: status matters? York: Joseph Rowntree Foundation.Fletcher, G. (2011). Finding routes for Refugees to use their skills and experience and contribute to the North East region's economic future. Gateshead, Regional Refugee Forum North East.

Foster, J. B., R. W. McChesney and R. J. Jonna (2011). "The Global Reserve Army of Labor and the New Imperialism." Monthly Review 11(1): 1-31.

Geddes, A., G. Craig and S. Scott with L. Ackers, O. Robinson and D. Scullion (2013) Forced Labour in the UK. York: Joseph Rowntree Foundation.

Gill, N. (2009). "Governmental mobility: the power effects of the movement of detained asylum seekers around Britain's detention estate." Political Geography 28(3): 186-196. Gill, N., D. Conlon, C. Oeppen and I. Tyler (2012). Networks of Asylum Support in the UK and USA: A Handbook of Ideas, Strategies and Best Practice for Asylum Support Groups in a Challenging Social and Economic Climate. http://www.esrc.ac.uk/my-esrc/grants/RES-00022-3928-A/outputs/Download/116f00b0-3bc0-484c-afa4-60476a64b8a7 [Accessed 05/09/12] Gilroy, P. (2001). Against Race: Imagining political culture beyond the color line.

Cambridge, The Belknap Press of Harvard University Press.

Griffiths, D., N. Sigona and R. Zetter (2005). Refugee Community Organisations and

Dispersal: Networks, resources and social capital. Bristol, The Policy Press.

Grossmann, H. ([1929] 1992). The Law of Accumulation and Breakdown of the Capitalist System. London, Pluto Press.

Hardy, J. 2008. Polish-UK Migration: Institutions, Capital and the Response of Organised Labour. EAEPE Conference "Labour, Institutions and Growth in a Global Knowledge Economy”. Rome.

Hewitt, R. L. (2002). Asylum-seeker Dispersal and Community Relations - An Analysis of Developmental Strategies. London: Centre for Urban and Community Research Goldsmiths College.

Hickman, B. (2002). "Police hunt four illegal immigrants: Asylum seekers go on the run." Evening Chronicle. Newcastle.

Home Office (2010). Control of Immigration: Quarterly Statistical Summary, United Kingdom January-March 2010. London.

Hynes, P., (2011). The Dispersal and Social Exclusion of Asylum Seekers: Between Liminality and Belonging, Bristol: Policy Press.

IAC (2008a) Fit for Purpose Yet? The Independent Asylum Commission's Interim Findings. London: Independent Asylum Commission. 
This is the author's accepted version of the following chapter: Vickers, T. (2015) 'The contribution of UK asylum policy 1999-2010 to conditions for the exploitation of migrant labour', in L. Waite, G. Craig, H. Lewis and K. Skrivankova (eds), Vulnerability, exploitation and migrants: Insecure work in a globalised economy, London: Palgrave MacMillan, pp 101-14. The version of record is available at:

IAC (2008b). Deserving Dignity: How to improve the way we treat people seeking sanctuary. London: Independent Asylum Commission.

Kay, D. and R. Miles (1992). Refugees or Migrant Workers? European volunteer workers in Britain 1946-1951. London, Routledge.

Lavalette, M. and A. Pratt (2006). Social Policy: Theories, Concepts and Issues. London: Sage.

Lenin, V. I. ([1916] 1975). Imperialism, the Highest Stage of Capitalism. Moscow: Progress Publishers.

Lenin, V. I. ([1917] 1972). The State and Revolution. Moscow: Progress Publishers.

Lewis, H, Dwyer, P., Hodkinson, S. and Waite, L. (2014) Precarious lives: forced labour, exploitation and asylum. Bristol, The Policy Press.

Marx, K. ([1894] 2006). Capital, Volume 3. London, Penguin.

Miles, R. (1987). Capitalism and Unfree Labour: Anomaly or necessity? London, Tavistock Publications.

ONS (2013a). The Pink Book 2013, Part 3: Geographical Breakdown. London: Office for National Statistics.

ONS (2013b). The Pink Book 2013, Part 1: Current Account. London: ONS.

ONS (2013c). Foreign Direct Investment Involving UK Companies, 2012. London: ONS.

Phillimore, J. and L. Goodson (2006). "Problem or opportunity? asylum seekers, refugees, employment and social exclusion in deprived urban areas." Urban Studies 43(10): 1715-1736. Philo, G., E. Briant and P. Donald (2013). Bad News for Refugees. London: Pluto.

Schuster, L. (2003). The Use and Abuse of Political Asylum. London: Frank Cass Publishers. Silverman, S. J. (2011). Immigration Detention in the UK. Oxford, The Migration Observatory.

Sporton, D. (2013). “"They Control My Life': the Role of Local Recruitment Agencies in East European Migration to the UK." Population, Space and Place 19(5): 443-458.

Taylor, D. (2013). 'Home Office accused of 'fixing' asylum figures. The Observer 27 October.

Taylor, D. and R. Mason (2014). "Home Office staff rewarded with gift vouchers for fighting off asylum cases". The Guardian 14 January.

Temple, B. and R. Moran, with N. Fayas, S. Haboninana, F. McCabe, Z. Mohamed, A. Noori and N. Rahman (2005). Learning to Live Together: Developing communities with dispersed refugee people seeking asylum. York: Joseph Rowntree.

Tyler, I. (2010). "Designed to fail: A biopolitics of British citizenship." $\underline{\text { Citizenship Studies }}$ 14(1): 61-74.

Vickers, T. (2012). Refugees, Capitalism and the British State: Implications for social workers, volunteers and activists. London: Ashgate.

Vickers, T. (2014a). "Developing an Independent Anti-Racist Model for Asylum Rights Organising in England.” Ethnic and Racial Studies 37(8), 1427-1447. 
This is the author's accepted version of the following chapter: Vickers, T. (2015) 'The contribution of UK asylum policy 1999-2010 to conditions for the exploitation of migrant labour', in L. Waite, G. Craig, H. Lewis and K. Skrivankova (eds), Vulnerability, exploitation and migrants: Insecure work in a globalised economy, London: Palgrave MacMillan, pp 101-14. The version of record is available at:

Vickers, T. (2014b). "Opportunities and Limitations for Collective Resistance Arising from Volunteering by Asylum Seekers and Refugees in Northern England.” Critical Sociology, DOI: $10.1177 / 0896920514526623$

Webber, F. (2012). Borderline Justice: the fight for refugee and migrant rights. London: Pluto.

\section{Notes}

i The implications of the global economic crisis of 2007 onwards are beyond the scope of this chapter, although it is important to note that while levels of labour migration dropped, the crisis did not remove Britain's structural dependency on migrants' labour (Sporton 2013).

ii A constructed category of refugees whose claims have not been accepted by the British state. iii A policy approach characterized by aggressive privatization and deregulation.

iv From 2005 asylum seekers could apply for permission to work if they had been waiting for 12 months for a decision on their asylum claim, although this could be granted or refused at the discretion of the Home Office. In 2010 further restrictions were introduced to limit the occupations those granted permission to work could undertake to a 'shortage list'.

$\mathrm{v} \quad$ Although the severity of refugee claims also has potential to produce a form of exceptionalism, with individual claims to asylum acknowledged while other needs-based claims continue to be ignored. 